\title{
Absorption of lactulose from mammalian gastrointestinal tract
}

\author{
BY D. F. EVERED AND F. SADOOGH-ABASIAN \\ Department of Biochemistry, Chelsea College (University of London), \\ Manresa Road, London $\mathrm{SW}_{3} 6 \mathrm{LX}$
}

(Received 28 April 1978 - Accepted 28 July I978)

\footnotetext{
I. The disaccharide lactulose (galactosyl- $\beta$-1,4-fructose) was poorly absorbed from rat small intestine in vitro and human mouth in vivo.

2. These results confirm indirect clinical evidence of poor absorption from the intestine.

3. The presence of calcium ions, or absence of sodium ions, had no effect on lactulose absorption from the buccal cavity.

4. The presence of ouabain, or absence of $\mathrm{Na}^{+}$, did not decrease the absorption of lactulose from small intestine.

5. It is thought that the mode of transport, in both instances, is by passive diffusion with the concentration gradient.
}

The disaccharide, lactulose (galactosyl- $\beta$-I,4-fructose) is apparently not readily absorbed from the human intestine thus leading to diarrhoea by its osmotic effect. Less than I $\%$ of a $5 \mathrm{~g}$ dose of lactulose given by mouth as a syrup was recovered in the urine of healthy adult subjects (Laker \& Menzies, 1977). The syrup contained small amounts of lactose and galactose.

The sweetness of lactulose and its poor absorption has suggested its use in diabetic foods (Birch, 1973). It is used therapeutically in hepatic encephalopathy and in chronic constipation. Infant diarrhoea was attributed to the adventitious presence of lactulose in certain commercial milk preparations fed to babies (Hendrickse et al. 1977).

We have studied the absorption of pure lactulose from rat small intestine in vitro and from the human buccal cavity in vivo. Previous studies have revealed that absorption of certain sugars from these different gastrointestinal sites shows many similarities (Manning \& Evered, 1976; McMullan et al. 1977).

\section{MATERIALS AND METHODS}

\section{Animals}

Male rats of the albino Wistar strain were used, body weight 200-250 $\mathrm{g}$. The rats were starved overnight but given water ad lib. Everted sacs of rat small intestine were prepared and used under the optimum conditions demonstrated for transport of D-glucose (Pritchard \& Porteous, 1977): $\mathrm{pH} \mathrm{7.4}$ Krebs-Ringer phosphate medium, $37^{\circ}, 95 \% \mathrm{O}_{2} / 5 \% \mathrm{CO}_{2}$ gas phase, and shaking at 80 oscillations/min for $30 \mathrm{~min}$. Having tested representative portions throughout the length of the small intestine most of the experiments utilized two $30 \mathrm{~mm}$ everted sacs selected at a point $100 \mathrm{~mm}$ from the pyloric sphincter of each rat. Experiments were of two types: 'uphill' when lactulose was present initially inside and outside the sac and 'downhill' when lactulose was present only outside the sac while the serosal surface inside was bathed with Krebs buffer. Protein was removed by isoelectric precipitation. Hexoses interfered with the lactulose assay so pyruvate, fumarate and L-glutamate were added as nutrient to the medium rather than the usual nutrient, glucose (Dawson et al. 1960). These compounds are all metabolized by the mucosa of the small intestine (Spencer \& Knox, 1960). Water transport was measured by weighing sacs initially and at the end of the experiment. 


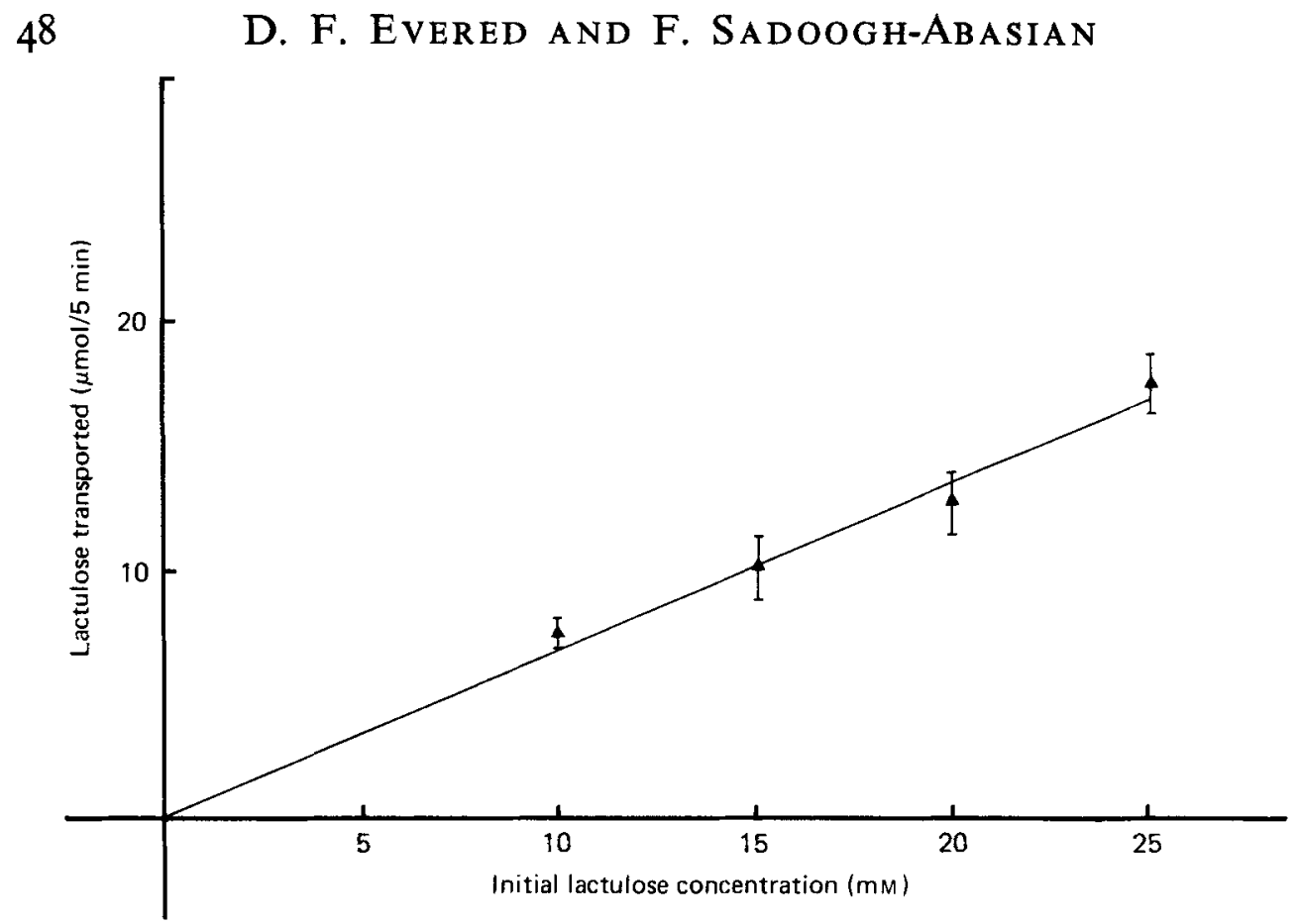

Fig. I. The effect of the concentration (mM) of lactulose (galactosyl- $\beta$-I,4-fructose) on absorption ( $\mu$ mol transported $/ 5 \mathrm{~min}$ ) across buccal mucosa in man. Points represent mean values, with their standard errors represented by vertical bars, for six experiments. For details of procedures, see p. 48 .

\section{Buccal absorption}

Absorption from the mouth entailed physiological buffers, a pre-incubation period and a buffer blank as a modification (Manning \& Evered, 1976) of the method of Beckett \& Triggs (1967). The subject for most of the buccal experiments was a male Caucasian aged 26 years who did not have dentures. Other subjects were a male aged 24 years and a female aged 30 years, both Caucasian.

\section{Assay}

Lactulose was measured spectrophotometrically by a fructose assay (Mahy et al. 1964).

Thin-layer chromatography (TLC)

TLC plates of aluminium sheets pre-coated with silica gel $60 \mathrm{~F}_{\mathbf{2 5 4}}, 0.2 \mathrm{~mm}$ thickness, were used. The solvent system was ethyl acetate-isopropanol-water (2:2:I) (Ghebregzabher et al. 1974). The sugars were detected by spraying with aniline-diphenylamine-acetonephosphoric acid $(800 \mathrm{ml} / \mathrm{l})(4: 4: 200: 30, \mathrm{v} / \mathrm{w} / \mathrm{v} / \mathrm{v})$ (Hansen, 1975). To separate lactose from lactulose the TLC plates were first impregnated with $0.032 \mathrm{M}$-sodium tetraborate and 0.05 M-sodium tungstate (3: I v/v) (Ghebregzabher et al. 1974).

\section{RESULTS AND DISCUSSION}

There was little difference in absorption of lactulose at different locations of the small intestine. At measured distances from the pyloric sphincter the mean ( $\pm \mathrm{SE}$; four experiments) absorption ( $\mu \mathrm{mol} /$ lactulose per $\mathrm{g}$ wet weight tissue) downhill of $20 \mathrm{~mm}$-lactulose

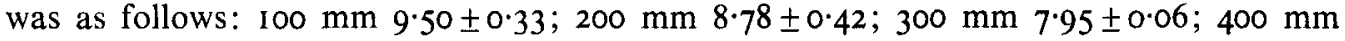
$9 \cdot 10 \pm 0 \cdot 20$. Our findings are in contrast to the maximal absorption of D-glucose at $350-400$ mm from the pylorus (Pritchard \& Porteous, I977). 


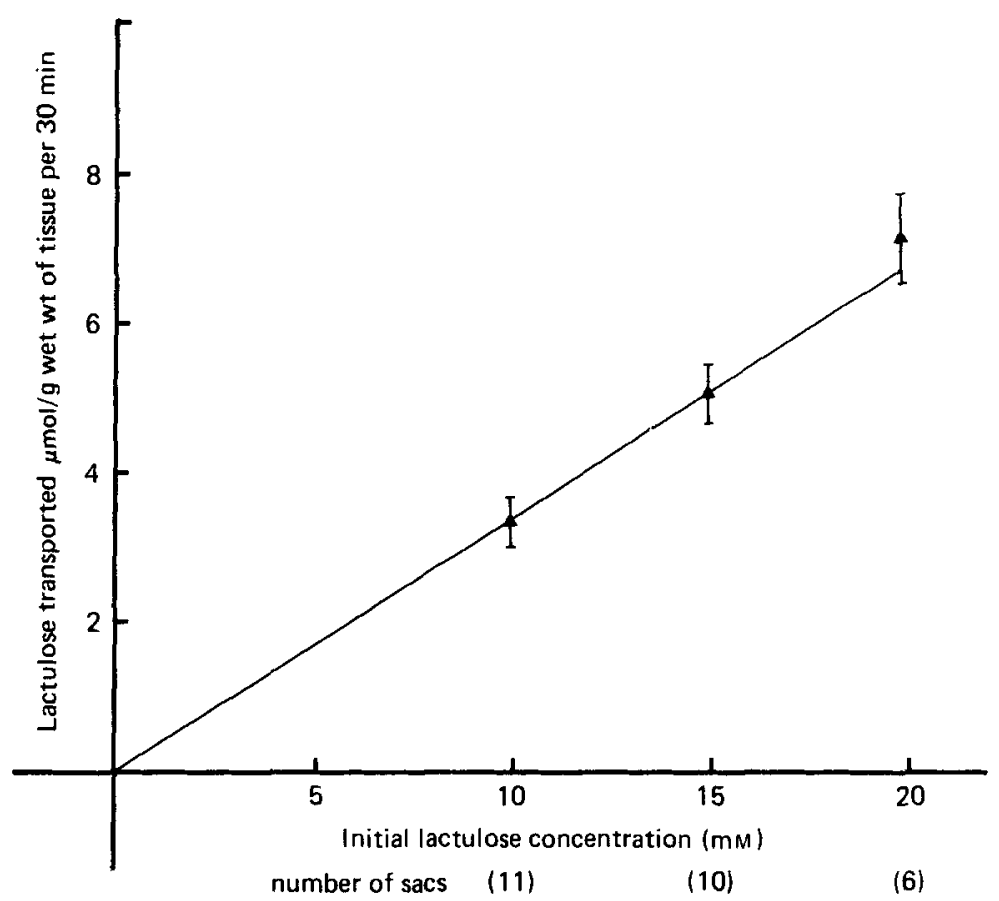

Fig. 2. The effect of the concentration (mM) of lactulose (galactosyl- $\beta$ - 1,4 -fructose) on absorption ( $\mu \mathrm{mol}$ transported $/ \mathrm{g}$ wet $w t$ of tissue per $30 \mathrm{~min}$ ) across the mucosa of small intestine of rat. Points represent mean values, with their standard errors represented by vertical bars for six experiments. For details of procedures, see p. 48.

With 5 mM-lactulose inside and outside the everted sac the mean serosal:mucosal concentration ratio was $0.9 \pm 0.02$ ( $\pm \mathrm{SE}$; six experiments). This numerical value being below unity can be attributed to water transport, a well-known phenomenon in such experiments (Pritchard \& Porteous, 1977).

With no lactulose within the sac initially, the plot of downhill transport $v$. the concentration gradient was approximately linear with increasing concentrations outside the sacs in the range 10-20 $\mathrm{mm}$ (Fig. I). Buccal absorption too was approximately linear with increasing lactulose concentration (Fig. 2). Different human subjects absorbed very similar small amounts of lactulose from the buccal cavity. Thus the mean ( $\pm \mathrm{SE}$; six experiments) amount of lactulose absorbed from the mouth in $5 \mathrm{~min}$ at $10 \mathrm{mM}$ concentration was $7.4 \pm$ $0.31 \mu \mathrm{mol}$ with the principal test subject. With another male subject the corresponding value was $7.7 \pm 0.46( \pm \mathrm{SE}$; six experiments) and with a female $6.7 \pm 0.50( \pm \mathrm{SE}$; three experiments) at $10 \mathrm{mM}$ concentration. Expressed as a percentage only $3 \%$ of the ro mM-lactulose was absorbed buccally compared with $\mathrm{I} 4-22 \%$ for the monosaccharide D-glucose (Manning \& Evered, 1976; Manning, 1977). Furthermore, buccal mucosa is not impermeable to all disaccharides since maltose was apparently quite well absorbed (Manning \& Evered, I976).

Absence of sodium ions, replaced by potassium ions, did not alter significantly the absorption of lactulose from the small intestine (Table I) or from the buccal cavity (Table 2 ). By contrast, active transport of $\mathrm{D}$-glucose is $\mathrm{Na}^{+}$-dependent in the intestine (reviewed by Schultz \& Curran, 1970) and buccal mucosa (Manning \& Evered, 1976).

The presence of the cardiac glycoside ouabain did not diminish lactulose absorption across everted sacs (Table I). Ouabain inhibits the membrane pump for sodium and 
Table I. Effect of ouabain and sodium ions on intestinal absorption of lactulose (galactosyl$\beta$-I,4-fructose) in the rat*

(Mean values with their standard errors; no. of experiments in parentheses)

\begin{tabular}{|c|c|c|c|}
\hline \multirow[b]{2}{*}{ Lactulose concentration (mM) } & \multicolumn{2}{|c|}{$\begin{array}{l}\text { Lactulose transported }(\mu \mathrm{mol} / \mathrm{g} \\
\text { wet tissue per } 30 \mathrm{~min})\end{array}$} & \multirow{2}{*}{$\begin{array}{c}\text { Statistical } \\
\text { significance } \\
\text { of difference between } \\
\text { treatments } \dagger\end{array}$} \\
\hline & Ouabain absent & (I mM) ouabain present & \\
\hline 15 & $\begin{array}{l}3.3 \pm 0.42(4) \\
\mathrm{Na}^{+} \text {present }\end{array}$ & $\begin{array}{l}5 \cdot 2 \pm 0 \cdot 24(4) \\
\mathrm{Na}^{+} \text {absent }\end{array}$ & 0.02 \\
\hline 25 & $10.7 \pm 0.62$ & $12 \cdot 1 \pm 0.65$ & NS \\
\hline & \multicolumn{3}{|c|}{$\begin{array}{l}\text { NS, not significant. } \\
\text { * For details of procedures, see p. } 48 . \\
\text { † Student's } t \text { test. }\end{array}$} \\
\hline
\end{tabular}

Table 2. Effect of calcium and sodium ions on buccal absorption of lactulose (galactosyl$\beta$-I,4-fructose) in the human*

\begin{tabular}{|c|c|c|c|}
\hline \multirow{2}{*}{ Lactulose concentration (mM) } & \multicolumn{2}{|c|}{ Lactulose transported $(\mu \mathrm{mol} / 5 \mathrm{~min})$} & \multirow{2}{*}{$\begin{array}{c}\text { Statistical } \\
\text { significance } \\
\text { of difference between } \\
\text { treatments } \dagger\end{array}$} \\
\hline & $\mathrm{Ca}^{2+}$ present $(2.6 \mathrm{mM})$ & $\mathrm{Ca}^{2+}$ absent & \\
\hline 20 & $\begin{array}{l}\mathrm{I} 2 \cdot \mathrm{I} \pm \mathrm{I} \cdot 5(3) \\
\mathrm{Na}^{+} \text {present }\end{array}$ & $\begin{array}{c}\mathrm{I} 2 \cdot 9 \pm \mathrm{I} \cdot \mathrm{I}(3) \\
\mathrm{Na}^{+} \text {absent }\end{array}$ & NS \\
\hline 25 & $18.8 \pm 0.81(3)$ & $18 \cdot 5 \pm 1 \cdot 3(3)$ & NS \\
\hline 15 & $I 0 \cdot I \pm I \cdot 09(6)$ & $10 \cdot 2 \pm I \cdot 8(6)$ & NS \\
\hline & \multicolumn{2}{|c|}{$\begin{array}{l}\text { NS, not significant. } \\
* \text { For details of procedures, see p. } 48 . \\
\dagger \text { Student's } t \text { test. }\end{array}$} & \\
\hline
\end{tabular}

therefore inhibits active transport of sugars (Crane, 1968). The unexpected increase in the absorption of lactulose in the presence of ouabain could be explained by inhibition of water transport. We found that I mM-ouabain inhibited transport of water in the presence of 15 mM-lactulose. The mean ( $\pm \mathrm{SE}$; four experiments) water transport (mg water transferred into each sac) was $78 \pm 2.8$ with ouabain and $94 \pm 8.9$ without ouabain.

The presence of calcium ions did not affect lactulose absorption across buccal mucosa (Table 2). Yet buccal absorption of D-xylose was stimulated by the presence of $\mathrm{Ca}^{2+}$. This calcium was thought to stimulate $\mathrm{Na}^{+}$fluxes and indirectly stimulate a glucose-carrier system in the buccal mucosa (McMullan et al. 1977). Similarly, calcium also stimulates uptake of certain sugars by everted segments of rat small intestine (Manning et al. 1978).

It was important to exclude possible hydrolysis of lactulose by bacteria or mucosae during the experiments. If there is any enzymic hydrolysis of $25 \mathrm{~mm}$-lactulose it was not detectable by TLC. Less than $0.9 \%$ of galactose and less than $2 \%$ of fructose was liberated in experiments with both small intestine and buccal mucosa. These are the limits of detection of these sugars in the TLC method used. Furthermore, there was no detectable lactose, i.e. less than $\mathrm{I} \%$, in the lactulose according to TLC. Lactulose is not hydrolysed by the action of intestinal disaccharidases (Dahlqvist \& Gryboski, 1965). Lactulose is either metabolized poorly, or not at all, in the human since urinary excretion after intravenous injection of lactulose is rapid and approaches $100 \%$ recovery within $12 \mathrm{~h}$ (Menzies, 1974).

Lactulose is fermented by gut bacteria. Ammonia assimilation by the bacteria in the presence of fermentable substrate like lactulose may be the rationale for lactulose therapy in porto-systemic encephalopathy (Vince et al. I978). 
In summary, it appears that the mucosae of rat small intestine and human buccal cavity both lack carrier systems for the disaccharide lactulose. Hence the poor absorption of lactulose from these two different sites in the gastrointestinal tract. All of the evidence presented here suggests that lactulose is absorbed across these mucosae by passive diffusion.

Lactulose was a gift from Duphar, Weesp, Holland.

\section{REFERENCES}

Beckett, A. H. \& Triggs, E. J. (1967). J. Pharm. Pharmac. 19, Suppl. 3Is.

Birch, G. G. (1973). Confect. Prod. 39, 73.

Crane, R. K. (1968). In Handbook of Physiology, p. 1323 [C. F. Code \& W. Heidel, editors]. Washington, DC: American Physiological Society.

Dahlqvist, A. \& Gryboski, J. D. (1965). Biochim. biophys. Acta 110, 635.

Dawson, R. M. C., Elliott, D. C., Elliott, W. H. \& Jones, K. M. (1960). Data for Biochemical Research, 2nd ed., p. 507 Oxford: Clarendon Press.

Ghebregzabher, M., Rufini, S., Ciuffini, G. \& Lato, M. (1974). J. Chromat. 95, 51.

Hansen, S. V. (1975). J. Chromat. 107, 224.

Hendrickse, R. G., Wooldridge, M. A. W. \& Russell, A. (1977). Br. med. J. I, I 194.

Laker, M. F. \& Menzies, I. S. (1977). J. Physiol., Lond. 265, 881.

McMullan, J. M., Manning, A. S. \& Evered, D. F. (1977). Biochem. Soc. Trans. 5, I 29.

Mahy, B. M. W., Rowson, K. E. K., Salaman, M. H. \& Parr, C. W. (1964). Virology $23,528$.

Manning, A. S. (1977). Specialised studies on the absorption of sugars across the mammalian gastrointestinal tract. PhD Thesis, University of London.

Manning, A. S. \& Evered, D. F. (I976). Clin. Sci. mol. Med. 51, I 27.

Manning, A. S., McMullan, J. M. \& Evered, D. F. (1978). Biochem. Soc. Trans. (In the Press).

Menzies, I. S. (1974). Biochem. Soc. Trans, 2, I042.

Pritchard, P. J. \& Porteous, J. W. (1977). Biochem. J. 164, I.

Schultz, S. G. \& Curran, P. J. (1970). Physiol. Rev. 50, 637.

Spencer, R. P. \& Knox, W. E. (I960). Fed. Proc. 19, 886.

Vince, A., Killingley, M. \& Wrong, O. M. (1978). Clin. Sci. mol. Med. 54, 33P. 